\title{
REVIEWS
}

\section{ZAPISKI RUSSKOI AKADEMICHESKOI GRUPPY V S.SH.A. / TRANSAC- TIONS OF THE ASSOCIATION OF RUSSIAN-AMERICAN SCHOLARS IN USA, vols. 1-9. New York: Association of Russian-American Scholars in USA, Inc., 1967-75. Vol. 1: 216 pp. \$3.50. Vol. 2: 271 pp. \$5.00. Vol. 3: 247 pp. $\$ 5.00$. Vol. 4: 248 pp. \$5.00. Vol. 5: 266 pp. \$5.00. Vol. 6: 334 pp. \$7.50. Vol. 7: 334 pp. \$7.50. Vol. 8: 298 pp. \$7.50. Vol. 9: 320 pp. $\$ 10.00$.}

As it approaches the end of its first decade, this series deserves far more attention than it has received to date among specialists in the Russian field. With a total of more than 2,500 pages in print, the Zapiski present a rich store of scholarly articles, along with useful biographical information on Russian scholars who have settled in this country.

Something about the sponsoring organization-the Russkaia Akademicheskaia Gruppa $v \operatorname{SSh} A$ (RAG) - can be learned from the short "Association News" section at the end of each volume. The Group was founded in 1948. From a core of six members it had grown to 150 by 1972 and to about 180 by 1975 , meanwhile having lost some 70 members through death. The original founders were Russian émigrés who, before coming to America, had known each other as faculty members of the international university sponsored in Munich immediately after World War II by the United Nations Relief and Rehabilitation Administration (UNRRA). Still earlier, they had been associated with various universities of the Russian Empire. By banding together in the RAG they sought to carry on the tradition of Russian scholarship in their newly adopted homeland. It was their intent that the Group should be open to all persons working in the field of Russian studies and that it should help to preserve Russian cultural traditions through lectures, research, conferences, and publications.

A few of the leading spirits of the Group must be mentioned even in a survey as short as this one. The initiator of the Group's organizational meeting in 1948 was a religious philosopher, Nikolai Sergeevich Arsen'ev (1888- ). A graduate of Moscow University in 1910, Arseniev taught there and at Saratov University before leaving Russia in 1920. In the interwar period he taught at the universities of Königsberg and Warsaw. In 1948 he became a professor at St. Vladimir's Theological Seminary in New York. He is the author of twenty-four books and numerous articles in the fields of religion, Russian culture, and philosophy. Arseniev has been one of the editors of the Zapiski since they began, and in 1970 he became the president of the Russian Academic Group.

Evgenii Vasil'evich Spektorskii (1875-1951), who served as the elected president of the Group from 1948 until his death, grew up in the Polish part of the Russian Empire and in 1898 graduated from Warsaw University in the field of law. After further studies there and in Western Europe, he taught at Warsaw. In 1913 he moved to Kiev University as professor of jurisprudence. In 1918 he was elected dean of the Juridical Faculty there, and then rector of the University. Emigrating in 1920, he taught at the universities of Belgrade, Prague, and Ljubljana before fleeing on foot into Italy in 1945. Narrowly escaping forced repatriation, he made his way to the United States in 1947 and joined the faculty of St. Vladimir's Seminary. Spectorsky's publications total more than 150 , including many books, and range across the fields of the history and philosophy of law, sociology, and religion.

Such odysseys characterize most if not all of the leading figures of the Group. Mikhail Mikhailovich Novikov (1876-1965), its president from 1951 until his death, 
was a zoologist who was twice elected rector of Moscow University before leaving with the expellees of 1922. Aleksandr Aleksandrovich Bogolepov (1886- ), the Group's president from 1966 to 1970 , is an expert in canon law who was the last freely elected prorector of Petrograd University (1920) and another member of the distinguished group of seventy expellees of 1922. The list could go on if space permitted, and would include many eminent scholars. One is struck by their continuing devotion to the academic tradition in the face of the most difficult circumstances.

At first the Group's activities were limited to the arranging of public lectures and conferences and the collecting of materials, and it still sponsors many lectures today. The Group's first big publication was a volume devoted to Spectorsky (1956). A sporadic publishing program over the next ten years led, in 1967, to the launching of the volumes of Zapiski or "Transactions" that have appeared yearly since then. The volumes have been published with help from the Humanities Fund for the early volumes and, since volume 6 , from the Tolstoy Foundation.

The editor in chief of the Zapiski since 1969 has been Konstantin Gavrilovich Belousov (1896- ). A graduate of the Petrograd Institute of Communications Engineering, Belousow (as he spells it now) served in the Russian army and then was severely wounded in the civil war. He emigrated to Czechoslovakia, where he became a civil engineer and university professor in Bratislava. As a refugee in Munich after the war, he was one of the organizers of the UNRRA-sponsored international university, and was elected dean of one of its faculties. Since 1947 he has been employed with the Power Authority of the State of New York. He is the author of several books and articles and the designer of many dams and power stations in Czechoslovakia and the United States. Serving with him as editors have been professors Arseniev and Bogolepov, along with Queens College geologist Eugene A. Alexandrov, NYU ophthalmologist Helene T. Biantovskaia Fedukowicz, Columbia geologist Waclaw S. Fedukowicz, Harvard fellow-in-residence and religious historian Richard V. Haugh, University of Pittsburgh Slavist Nicholas P. Poltoratzky, retired Yale historian Sergei G. Pushkarev, and historian Alexis P. Scherbatow of Fairleigh Dickinson University. Others who have served as editors are Slavist Victor N. Litwinowicz, historian Nickolas B. Lupinin, physician-surgeon Peter S. Schidlowsky, and, until their recent deaths, Slavist Boris O. Unbegaun and historian George V. Vernadsky. A friend informs me that, although many people have helped, it is really Belousow who does most of the work and by his dedication has made this whole series possible. The offices of the RAG and of the Zapiski are in his home at 85-20 114th Street, Richmond Hill, New York 11418. In his eightieth year, he is not yet fully retired from his engineering duties but contributes most of his time to the Group and its Zapiski.

The contents of the series have remained fairly uniform since the second of the nine volumes. The first volume was almost entirely in Russian and contained several personal memoirs. All of the other volumes have been partly in English and have consisted almost wholly of scholarly articles. Articles in Russian have occupied over twothirds of the total space so far. In recent issues the Russian share has been somewhat less than two-thirds, but still well over half. In volumes 1-5, most of the Russian articles were accompanied by a short summary in English, and vice versa, but this practice has been dropped in subsequent volumes.

Beginning with volume 5, part of each volume has included a cluster of articles derived from a symposium. These symposia have treated Dostoevsky (1971), Solzhenitsyn (1971), Acmeism (1972), Peter the Great (1973), Gulag Archipelago (1974), and Pushkin (1975). One symposium was held at Fordham with the assistance of Paul Trensky; the rest have been at Hunter College with the help of Filia Holtzman and Alex E. Alexander. Another special feature, this one appearing in four of the last five volumes, is a short section of English translations of primary sources in Russian 
history. These have been done by younger historians of the Group who have evidently been educated in this country-Haugh, Lupinin, Scherbatow, Vladimir Danilov, and Nicholas G. Itsines. Most volumes have contained notices of members' books. At the end of each volume a few pages are devoted to association news: business meetings of the Group, symposia, lectures by various members, and other matters of interest. Especially important in this last section are the biographies of members, sometimes presented after their deaths and sometimes included to mark special birthdays.

Almost all of the scholarly articles to date have dealt with Russia. The main exceptions have been in medicine and philosophy. The distribution of pages by disciplines has been approximately as follows: history, general (including political, economic, and intellectual history) - 1,006; literature and philology - 609; art and history of art 162 ; history of science -129 ; history of religion - 115 ; sociology and demography 98; political science and law - 51; philosophy - 48; geography and geology - 42; and other natural sciences -40 . The number of articles to date, not counting obituaries and other items of association news, is about 129 . Some of the contributors have written more than one article, and I would estimate the number of individual authors at about seventy-five. In volume 6, editor Belousow indicated that up to that time fifty of the fifty-seven authors had been members of the Group. The proportion of nonmembers is evidently somewhat higher now, with the publication of articles from the symposia. But even if the volumes include mainly articles by members, this hardly constitutes a barrier to those who wish to submit manuscripts, since membership is essentially open to any qualified professionals in the Russian field. ( $\mathrm{I}$ am told that an applicant is usually expected to have at least a master's degree, and to demonstrate a serious academic interest in Russia.) The published instructions for contributors indicate that each manuscript will be sent to two referees for appraisal before the editor decides whether it can be accepted. Misprints and other slips were fairly common in the first four volumes. In the more recent volumes, the technical quality of the editing has been much better. Footnoting practice varies. Some articles have few specific citations but provide a bibliographical note at the end; others are footnoted in great detail.

As one looks over the nine volumes, one sees some authors' names repeatedly. An important feature of volumes 5 through 9 is George Vernadsky's "Ocherki po istorii nauki $v$ Rossii." This is a book-length study intended for publication serially in the Zapiski. Notwithstanding its broad title, it is mostly a history of Russian historians. It deals with the period from 1725 to the present day, but the treatment of recent decades is incomplete because Vernadsky died while the work was in progress. Two editors of the Zapiski, acceding to the wishes of their colleagues, agreed to research and write those sections that Vernadsky had outlined but not yet elaborated: Pushkarev contributed a 64-page chapter for volume 8 on the historiography of the Russian church, while Scherbatow wrote a 20-page chapter for volume 9 on Russian scholars specializing in Asian Studies. One may also consider as an appendix to Vernadsky's final work a 13-page list of his 197 publications and a richly informative biographical article on Vernadsky done for volume 9 by Nikolay E. Andreyev of Cambridge University. This all adds up to the equivalent of a book of about 450 pages, not extensively footnoted but containing many bibliographical listings. It cannot be given an appropriately detailed appraisal here. Along with its general sections it includes individual sketches of more than eighty Russian historians. Some of these are disappointingly incomplete. The two pages on Sigizmund N. Valk (vol. 8, pp. 152-53), for example, do not begin to measure up to Joan Afferica's eight pages on Valk in the December 1975 Slavic Review. But many of the sketches are extensive. They express Vernadsky's accumulated wisdom and mature judgments stemming from his own reading of these historians' works and from his personal acquaintance with many of them. This final 
survey from Vernadsky's pen has special value and should be listed among his major publications.

The articles by Pushkarev, Vernadsky's colleague and friend in both Prague and New Haven, are another important feature of the first nine volumes of the Zapiski. Pushkarev's articles in the nine volumes total about 250 pages. In addition to his article on historians of the Russian Orthodox church in volume 8, Pushkarev has done sizable articles on the Time of Troubles (vol. 1), the Don Cossacks and the Muscovite State in the seventeenth century (vol. 2), Lenin's foreign policy in the period 1914-23 (vol. 4), and Peter the Great (vol. 7), plus a moving obituary on Vernadsky (vol. 7) and a short piece marking the 250th anniversary of the Russian Academy of Sciences (vol. 9). In these works Pushkarev displays his customary combination of erudition, human interest, and occasional humor, all set forth in a Russian that is careful, clear, and at times eloquent.

Still another major contribution to the contents of the first nine volumes has been made by Nicholas Arseniev, mentioned above as one of the founders of the Russian Academic Group. Arseniev has had articles in eight of the first nine volumes. He has written on his personal recollections of Moscow University in 1906-10 (vol. 1), Russian family traditions (vol. 2), religious life in the Middle Ages (vol. 3), Romantic images of Italy (vol. 4), Dostoevsky (vol. 5), and Pushkin (vol. 9), plus shorter items. Two of Arseniev's articles are in English. Among the other contributors of three or more articles in the first nine volumes are Hunter College Slavist Alex E. Alexander, chief editor Belousow, Oberlin Slavist John B. Dunlop, editor Haugh, New York art historian (and banker) Nikita D. Lobanov-Rostovsky, the late Albany Slavist Marianna A. Poltoratzky, Lafayette College chemist George A. Siemiencow, and Berkeley Slavist Gleb P. Struve. There are also posthumous pieces by Nikolai O. Lossky and Eugene V. Spectorsky, among others.

Constantine Belousow and his colleagues have much to be proud of in the nine volumes they have produced to date.

RALPH T. Fisher JR. University of Illinois at Urbana-Champaign

THE MAKING OF A MISSILE CRISIS: OCTOBER 1962. By Herbert S. Dinerstein. Baltimore and London: The Johns Hopkins University Press, 1976. xiv, 302 pp. $\$ 14.95$.

The Cuban missile crisis, if it is to be defined as that period between August 1962, when American U-2 reconnaissance planes photographed eight SAM-2 missile sites in Cuba, and October, when ground to ground medium and intermediate range missiles were removed by the Soviet Union, has been well recorded by historians and dramatists. But Professor Dinerstein's highly researched book gives the reader an insight into the causes of the crisis dating back to when the Soviets first introduced arms into Latin America in Guatemala in 1954 at the peak of the Cold War.

According to Dinerstein, faulty perceptions, miscalculations, and varying theories within and among the three involved nations led to a situation that none of the three desired and all could have avoided. Castro saw American imperialist counterrevolution and the eventual invasion of Cuba as the greatest threat to his revolution. The Soviet Union, only passively supporting Cuba at first, saw an opportunity to place its missiles within range of the United States for the first time, and thereby partially offset American missile bases overseas. At the same time, the USSR wanted to protect a budding socialist state in the Western Hemisphere under the umbrella of nuclear threat. 